\title{
RÓŻNICE W ZACHOWANIACH ZDROWOTNYCH I KOSZTACH LECZENIA KOBIET I MĘŻCZYZN W POLSCE
}

\section{Wprowadzenie}

$\mathrm{Z}$ różnic w zachowaniach zdrowotnych między kobietą a mężczyzną wynikają odrębne potencjalne zagrożenia dla zdrowia dotyczące płci. Ujawnianie i analizowanie tych różnic powinno się odbywać poprzez pryzmat zarówno uwarunkowań behawioralnych, jak i na poziomie uwarunkowań i determinant ekonomicznych.

Celem opracowania jest analiza niekorzystnych zachowań zdrowotnych kobiet i mężczyzn oraz próba oceny społecznych i ekonomicznych konsekwencji, które przejawiają się poprzez wyższe koszty udzielanych świadczeń zdrowotnych.

\section{Zachowania zdrowotne - pojęcia ogólne}

Zachowania zdrowotne (health behaviour) są postawami wobec własnego zdrowia, kształtowanymi od wczesnego dzieciństwa m.in. w procesie edukacji zdrowotnej. Proces ten zachodzi w rodzinie, w szkole, w grupie rówieśników ${ }^{1}$. Przez zachowania zdrowotne należy rozumieć też wszelkie działania polegające na dokonywaniu określonych wyborów zarówno dotyczących własnego zdrowia, jak i zdrowia innych osób (palący papierosy nie tylko sam wdycha dym nikotynowy, ale również jego otoczenie).

Zachowania zdrowotne to działania związane ze zdrowiem. W ich skład wchodzą zachowania wspomagające (pozytywne) oraz szkodzące zdrowiu (negatywne). Wśród pozytywnych można wymienić np. prawidłowe odżywianie, utrzymywanie

1 Zachowania zdrowotne ludzi ściśle wiążą się ze sposobem postępowania wraz z poczuciem odpowiedzialności za swoje zdrowie, które zgodne jest m.in. innymi z zaakceptowanym systemem wartości. W strategii WHO „Zdrowie dla wszystkich w roku 2000” oraz koncepcji promocji zdrowia podkreśla się, że zdrowie związane jest ściśle z postawami zdrowotnymi, dzięki którym jednostka lub grupa może urzeczywistniać swoje cele, realizować zadania i zaspokajać potrzeby. 
sprawności ruchowej i psychicznej, zachowanie higieny osobistej, nienadużywanie leków czy alkoholu². Do tej grupy zalicza się również utrzymywanie właściwych stosunków międzyludzkich. Natomiast wśród zachowań negatywnych można wymienić np. palenie tytoniu, nadużywanie alkoholu, nieprawidłową dietę, brak ruchu, nadmierny stres ${ }^{3}$. Zbliżony podział zachowań zdrowotnych dzieli je na zachowania:

- prozdrowotne, które podtrzymują i utrwalają nasze zdrowie;

- antyzdrowotne, które szkodzą zdrowiu, są nieprawidłowe i ograniczają potrzeby organizmu;

- mieszane, jednocześnie prozdrowotne i antyzdrowotne; można tu przytoczyć przykład zachowania osób uprawiających sport, które przestrzegają wielu wskazań zdrowotnych, a równocześnie palą papierosy.

Należy dodać, że w kształtowaniu zdrowia istotna jest znajomość nie tylko zachowań korzystnych dla zdrowia, ale również zachowań negatywnych i ich podłoża społecznego oraz indywidualnego.

Działania prozdrowotne dotyczą unikania chorób czy też zabezpieczania się przed nimi. Są one związane z różnymi czynnikami, do których można zaliczyć np. nawyki, zwyczaje, przyzwyczajenia czy postawy wobec zdrowia, wierzenia. Wymieniane są jeszcze inne czynniki, które leżą u podstaw zachowań zdrowotnych. Są nimi: 1) poziom wiedzy i umiejętności każdego człowieka dotyczący uwarunkowań zdrowia;

2) warunki ekonomiczne i polityczne kraju, które determinują możliwości instytucjonalne ochrony zdrowia;

3) warunki społeczne związane z postrzeganiem własnego zdrowia ${ }^{4}$.

Przedstawiona lista czynników wpływających na zachowania zdrowotne nie jest kompletna oraz bardzo ogólna. Nie nadaje im rangi co do istotności i wagi poszczególnych elementów. Powoduje to, że każdy z wymienionych komponentów w takim zapisie ma identyczne znaczenie, chociaż w rzeczywistości np. poziom wiedzy każdego człowieka oraz umiejętności poszczególnych osób są uzależnione od świadomości zdrowotnej, a ta od poziomu edukacji, w tym edukacji zdrowotnej.

Czynniki determinujące zachowania zdrowotne mogą zostać zapisane w postaci modelu. Jeden $\mathrm{z}$ nich zakłada, że głównymi czynnikami wpływającymi na zdrowie są następujące elementy: indywidualna percepcja zdrowia, czynniki modyfikujące

\footnotetext{
2 B. Uramowska-Żyto, Zachowania żywieniowe i edukacja żywieniowa z perspektywy socjologicznej, „Promocja Zdrowia. Nauki Społeczne i Medycyna” 1996, nr 5-6.

3 Istnieje wiele określeń na negatywne zachowania zdrowotne, np. antyprozdrowotne, szkodzące zdrowiu. Można też spotkać termin „zachowania ryzykowne”, jest to jednak stosunkowo mało precyzyjne i nie do końca adekwatne pojęcie.

${ }^{4}$ V. Korporowicz, Promocja zdrowia. Kształtowanie przyszłości, Oficyna Wydawnicza SGH, Warszawa 2008, s. 86.
} 
zachowania zdrowotne oraz prawdopodobieństwo zastosowania określonego działania.

Do indywidualnej percepcji zdrowia można zaliczyć świadomość wystąpienia konkretnej choroby oraz świadomość niebezpieczeństwa i zagrożenia daną chorobą, które są kształtowane przez czynniki modyfikujące zachowania zdrowotne: demograficzne (wiek, płeć, rasa), socjopsychologiczne (osobowość, klasa, przynależność do grupy społecznej) oraz zróżnicowania strukturalne, np. wiedza na temat konkretnej choroby. Do tej grupy czynników należy również zaliczyć różnego typu informacje dotyczące danej choroby. Są to informacje uzyskane ze środków masowego przekazu, od innych osób, z różnego typu źródeł dotyczących chorób czy doświadczenia rodzinnego. Wszystkie te czynniki mają określony wpływ na możliwość wystąpienia konkretnej choroby. Potencjalne zagrożenie chorobą oraz świadomość korzyści i barier towarzyszących zastosowaniu środków ochronnych są częścią prawdopodobieństwa zastosowania określonego działania, które wpływa na zachowania mające na celu niedopuszczenie do zaistnienia konkretnej choroby ${ }^{5}$.

Przedstawiony model zachowań zdrowotnych jest dość szczegółowy i uwzględnia liczne warunkujące je czynniki. Brak jest w nim jednak pewnych elementów, np. kulturowych czy politycznych, które mocno oddziałują na zachowania społeczne, w tym zdrowotne. Należy również dodać, że czynniki te nie są jedynymi determinantami zdrowia i same mają swoje uwarunkowania środowiskowe, kulturowe czy społeczno-ekonomiczne. Ważne jest też stwierdzenie, że zachowania zdrowotne to nie tylko indywidualne, ale i zbiorowe działania związane z życiem jednostki, na które może ona nie mieć wpływu, np. bezrobocie czy kryzysy gospodarcze, które determinują status ekonomiczny oraz społeczny, co bezpośrednio wpływa na zachowania zdrowotne.

\section{Wybrane negatywne zachowania zdrowotne kobiet i mężczyzn w Polsce}

Istnieje wiele typologii oraz klasyfikacji zachowań zdrowotnych, wśród których jest podział na pozytywne i negatywne. Do negatywnych zachowań zdrowotnych można zaliczyć palenie papierosów, alkoholizm, narkomanię.

\footnotetext{
5 J. Kemm, A. Close, Health promotion. Theory and practice, MacMillan, London 1995, s. 114-115.
} 


\subsection{Palenie papierosów (nikotynizm)}

W Polsce notowane jest, po pierwsze, duże natężenie palenia, gdyż mężczyźni palą średnio 18 papierosów dziennie, kobiety - 13 papierosów, a po drugie - wieloletnie palenie, średnio około 23 lata w ciągu życia zarówno kobiet, jak i mężczyzn ${ }^{6}$. Jeżeli następuje zaprzestanie palenia, to następuje ono stosunkowo późno - wśród mężczyzn w 39 roku życia, a wśród kobiet nawet w 43 roku życia ${ }^{7}$.

\section{Rysunek 1. Codziennie palący mężczyźni i kobiety w Polsce powyżej 15 roku życia (Polska 2009-2011) (w \%)}

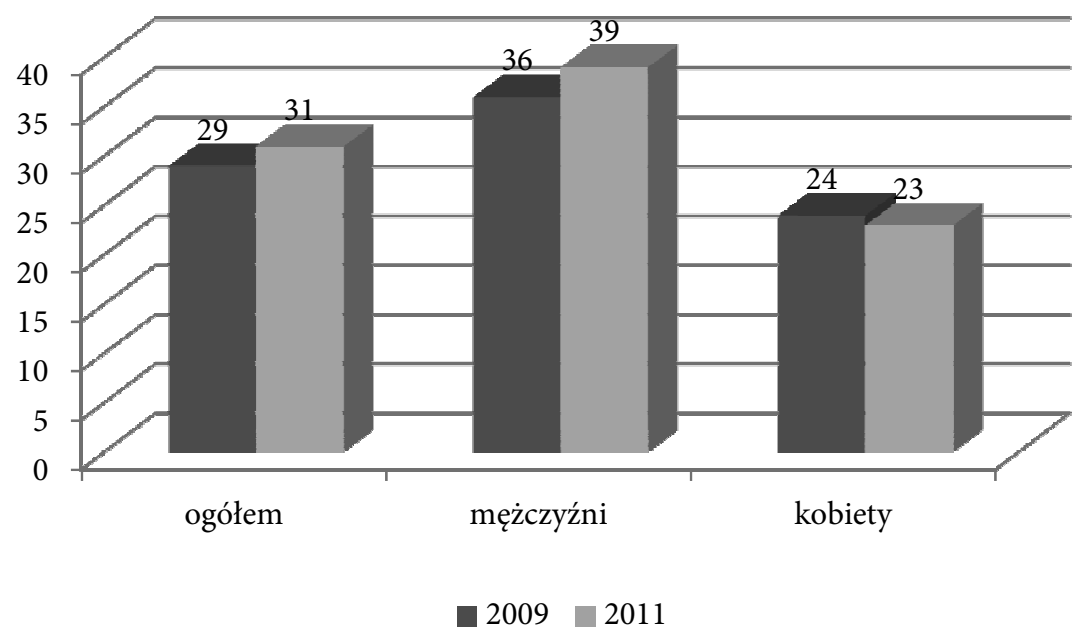

Źródło: http://www.gis.gov.pl/ckfinder/userfiles/files/PZ/Raport\%20og\%C3\% B3lnopolski\%20\%202011 (15.08.2012).

Obserwacje te potwierdzają badania wykonane w okresie od 3 do 6 lutego w $2011 \mathrm{r}$. wraz z badaniem traktowanym jako punkt odniesienia przeprowadzonym $\mathrm{w}$ terminie od 23 do 26 lipca 2009 r. przez TNS OBOP na zlecenie Głównego Inspektoratu Sanitarnego. Badania te wskazały, że mężczyźni w Polsce palą papierosy częściej niż kobiety, gdyż w latach 2009-2011 38\% mężczyzn deklarowało codzienne palenie papierosów, natomiast kobiet - 23\% (rysunek 1$)^{8}$. Nie można też pominąć faktu, że w badanych latach wśród mężczyzn obserwuje się tendencję wzrostową zażywania

\footnotetext{
${ }^{6}$ Raport na temat palenia tytoniu w Polsce - Biuro WHO w Polsce.

7 Na podstawie ogólnopolskich badań ankietowych z 2007 r. wykonanych przez Zakład Epidemiologii i Prewencji Nowotworów Centrum Onkologii - Instytut w Warszawie we współpracy z TNS OBOP w ramach Programu Prewencji Pierwotnej Nowotworów Złośliwych.

8 W $2011 \mathrm{r}$. badanie wykonano techniką wywiadu bezpośredniego w domach respondentów na reprezentatywnej próbie 1005 osób wśród osób powyżej 15 roku życia, natomiast w 2009 r. badano również metodą wywiadu kwestionariuszowego na próbie reprezentatywnej liczącej 1003 osób.
} 
tytoniu: z 36\% do 39\%. Wśród kobiet nieznaczna jest tendencja spadkowa: z 24\% do 23\%. Tendencje te potwierdzają inne badania z 2008 r., z których wynika, że odsetek codziennie palących mężczyzn wynosił $34 \%$, okazjonalnie palących $-2 \%$, byłych palaczy - 19\%. W populacji kobiet wielkości te są niższe, gdyż codziennie palących zanotowano $23 \%$, okazjonalnie - 3\%, byłe palaczki stanowiły $10 \%$. Mężczyzn nigdy niepalących odnotowano $45 \%$, a kobiet $-64 \%$.

Zgodnie z badaniami OBOP z 2011 r. elementem różnicującym częstotliwość palenia poza płcią (w którym to aspekcie zdecydowanie częściej zażywają nikotyny mężczyźni) jest wykształcenie (rysunek 2). I tak palą głównie mężczyźni o wykształceniu zawodowym - 57\% oraz średnim - 36\%. Wśród kobiet, które zdecydowanie mniej palą papierosów, elementem wyróżniającym jest również, podobnie jak w przypadku mężczyzn, wykształcenie - odpowiednio 38\% i $23 \%$.

Kolejnym zagadnieniem podjętym w cytowanym już badaniu OBOP z $2011 \mathrm{r}$. jest częstotliwość zażywania nikotyny z uwzględnieniem wieku palaczy. Dominującą grupą wiekową wśród mężczyzn i kobiet jest populacja w wieku 50-59 lat. Są to zatem osoby starsze. Niepokojącym zjawiskiem jest duża grupa palaczy w wieku 20-29 lat, która wśród mężczyzn stanowi aż 30\%, a wśród kobiet - 23\%. Badanie wykazało, że również spora grupa dzieci w Polsce w wieku 15 lat podejmuje próby palenia.

Zbliżone trendy w zakresie zażywania nikotyny prezentują też starsze badania ${ }^{10}$. Zgodnie z nimi w Polsce w 2004 r. aż 1/4 badanej młodzieży w wieku 15 lat paliła tytoń, w tym: 12,4\% uczniów paliło codziennie, częściej palili chłopcy (14,9\%) niż dziewczęta $(10,1 \%)^{11}$.

Jak wynika z innych badań OBOP z 2008 r., wśród młodzieży niepalącej dominują dziewczęta. Niepalenie zadeklarowało $64 \%$ dziewcząt w porównaniu z 59\% chłopców. Natomiast w 2005 r. niepalących dziewcząt było 53\% wobec $48 \%$ chłopców, a zatem różnice miedzy płciami utrzymały się na poziomie 5 pkt. proc. Niepaląca młodzież w Polsce to najczęściej uczniowie liceów ogólnokształcących zarówno publicznych, jak i prywatnych, odpowiednio 66\% i 68\%. Ponadto papierosów nie pali

9 W. Zatoński, K. Przewoźniak, Palenie tytoniu oraz opinie na temat polityki zdrowotnej $w$ Polsce w 2007 r., Instytut Onkologii, Warszawa, 2008, s. 30.

10 K. Krajewski-Siuda, Polskie narzędzie zapewniania jakości samorządowych programów promocji zdrowia, Wydawnictwo Śląskiej Akademii Medycznej, Katowice 2006, s. 26-54.

11 Kolejne badania dotyczące nikotynizmu wśród młodzieży, przeprowadzone w latach 1992-2003 , wskazywały stopniowy wzrost odsetka uczniów regularnie palących papierosy (z 23\% do 31\%). $\mathrm{W}$ wynikach sondaży dostrzec można zmiany notowanej tendencji. Regularne palenie deklaruje $22 \%$ badanych, czyli mniej niż $\mathrm{w}$ jakimkolwiek $\mathrm{z}$ dotychczasowych badań. Jednocześnie można było zaobserwować znaczny wzrost odsetka uczniów niepalących, tzn. około $62 \%$ młodzieży twierdziło, że nie pali papierosów. Najliczniejsza grupa młodych ludzi deklarowała niepalenie w 1996 r. (60\%), a najmniej niepalących było w 2003 r. (50\%). Jeśli chodzi o palenie okazjonalne, to możemy mówić o sytuacji stabilnej, w latach 1992-2008 odsetki w tej grupie wahają się od 15\% do 18\%. 
60\% uczniów liceów profilowanych, zawodowych i technicznych oraz $42 \%$ uczniów zasadniczych szkół zawodowych. Deklaracje regularnego palenia papierosów są najczęstsze w zasadniczych szkołach zawodowych. W 2006 r. regularnie paliło tam 41-42\% uczniów. Natomiast w publicznych i prywatnych liceach ogólnokształcących regularnie palenie deklarowało odpowiednio 17\% (spadek w stosunku do $2003 \mathrm{r}$. o 7 pkt.) i $18 \%$ (spadek o 17 pkt.) ${ }^{12}$.

\section{Rysunek 2. Codziennie palący według płci i typu wykształcenia w 2011 r. (w \%)}

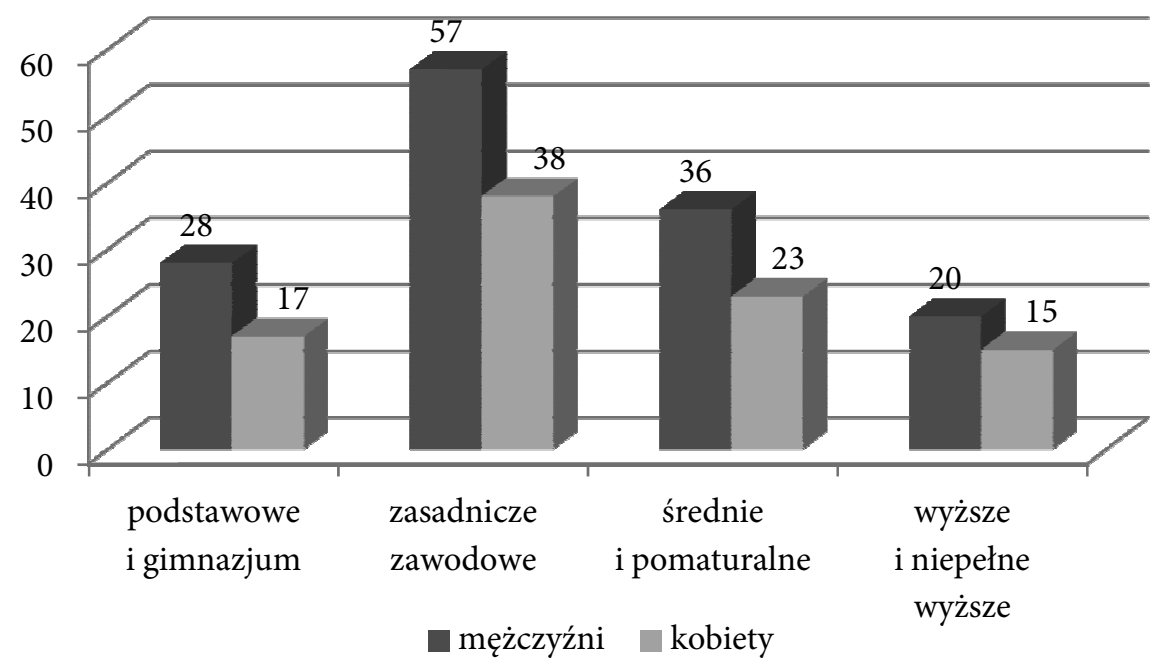

Źródło: jak do rysunku 1.

Istnieją też dysproporcje regionalne w liczbie wypalanych papierosów przez mężczyzn i kobiety. Najwięcej mężczyzn, którzy palą papierosy codziennie, jest w województwie warmińsko-mazurskim (około 40\%), a kobiet - w województwie zachodniopomorskim (około 36\%). Natomiast wśród mężczyzn najmniej (około 30\%) - w województwie mazowieckim, a wśród kobiet - w województwie małopolskim (około 23\%) ${ }^{13}$.

Warto też zwrócić uwagę, że nie tylko samo palenie jest niebezpieczne dla zdrowia. Bardzo groźne jest również bierne palenie. Szczególnie niebezpieczna jest sytuacja dzieci palących rodziców, które są poddawane działaniu dymu tytoniowego już w okresie płodowym. Ocenia się, że każdego roku w Polsce rodzi się okolo 100 tys. dzieci, które narażone są na kontakt $\mathrm{z}$ dymem tytoniowym z powodu palenia przez kobiety w ciąży.

12 http://www.OBOP.tnsglobal.pl/archive-report/id/1367 (06.08.12).

13 V. Korporowicz, Równość płci? Między fikcja a prawda, w: Wspótczesne problemy demograficzne. Rzeczywistość i mity. Ujęcie krajowe, regionalne i globalne, red. J. Osiński, Oficyna Wydawnicza SGH, Warszawa 2011, s. 472. 


\subsection{Alkoholizm}

Szacuje się, że w Polsce około 4,5 mln osób nadużywa alkoholu, w tym 600-900 tys. jest uzależnionych i wymaga leczenia ${ }^{14}$. Mężczyźni piją najwięcej między 20 a 30 rokiem życia i osiem razy częściej uzależniają się niż kobiety ${ }^{15}$. Rośnie także liczba uzależnionych kobiet. Jeszcze przed kilku laty nie przekraczały one liczby $3 \%$ wśród wszystkich alkoholików, obecnie mówi się o 8-10\%, przy czym u kobiet do uzależnienia dochodzi szybciej i w młodszym wieku. U kobiet choroba alkoholowa występuje najczęściej między 30 a 40 rokiem życia. Szacuje się, że nawet kilka tysięcy dzieci pijących matek pozbawione zostaje możliwości pełnego fizycznego i intelektualnego rozwoju, rodząc się z objawami zespołu alkoholowego, który nabywają już w życiu płodowym. To powoduje, że w ciągu życia cierpią na poważne zaburzenia somatyczne i psychiczne.

Najwyższe spożycie alkoholu w Polsce notowano w latach 1979 i 1980, kiedy to na jednego statystycznego mieszkańca wypadało 8,5 1 100\% alkoholu. W późniejszych latach nastąpił spadek do poziomu około 6,5 l, równocześnie jednak oceniano, że faktyczne spożycie alkoholu może być wyższe o 30\%, gdyż alkohol pochodzi też

14 Ustawa z dnia 26 października 1982 r. o wychowaniu w trzeźwości i przeciwdziałaniu alkoholizmowi. (DzU $2002 \mathrm{nr} 147$ poz. 1231) mówi w:

art. 46.2. Stan po użyciu alkoholu zachodzi, gdy zawartość alkoholu w organizmie wynosi lub prowadzi do:

1) stężenia we krwi od $0,2 \%$ do $0,5 \%$ alkoholu albo

2) obecności w wydychanym powietrzu od $0,1 \mathrm{mg}$ do 0,25 mg alkoholu w $1 \mathrm{dm}^{3}$.

3. Stan nietrzeźwości zachodzi, gdy zawartość alkoholu w organizmie wynosi lub prowadzi do:

1) stężenia we krwi powyżej 0,5\%o alkoholu albo

2) obecności w wydychanym powietrzu powyżej 0,25 $\mathrm{mg}$ alkoholu w $1 \mathrm{dm}^{3}$.

Art. 47.1. Jeżeli zachodzi podejrzenie, że przestępstwo lub wykroczenie zostało popełnione po spożyciu alkoholu, osoba podejrzana może być poddana badaniu koniecznemu do ustalenia zawartości alkoholu w organizmie, w szczególności zabiegowi pobrania krwi. Zabiegu pobrania krwi dokonuje fachowy pracownik służby zdrowia.

15 Alkoholizm (uzależnienie od alkoholu) - choroba demonstrująca utratę kontroli nad ilością spożywanego alkoholu. W odróżnieniu od innych rodzajów substancji psychoaktywnych, $\mathrm{w}$ alkoholizmie występuje głównie uzależnienie psychiczne, natomiast somatyczne objawy abstynencyjne są dość nikłe. $\mathrm{W}$ alkoholizmie w miarę rozwoju nałogu spadła tolerancja na picie.

Aby mówić o chorobie alkoholowej, muszą wystąpić minimum trzy z wymienionych objawów. Do objawów tych należą: silna natrętna potrzeba spożywania alkoholu, upośledzona zdolność kontrolowania picia alkoholu, objawy abstynencyjne, np. drżenia mięśniowe, nadciśnienie tętnicze, bezsenność, rozszerzenie źrenic, zanik pamięci, zmieniona tolerancja na alkohol, narastające zaniedbywanie alternatywnych do picia przyjemności, zachowań i zainteresowań, picie alkoholu mimo oczywistej wiedzy o jego szczególnej szkodliwości dla zdrowia pijącego. 
z nielegalnej produkcji. W latach 90. spożycie zaczęło znowu wzrastać i ocenia się, że obecnie wynosi ono około 101 100\% alkoholu na mieszkańca ${ }^{16}$.

Alkoholizm jest ważnym problemem społecznym w Polsce. Potwierdzają to badania przeprowadzone nad postawami i zachowaniami zdrowotnymi młodzieży. Badaniem objęta była młodzież trzecich klas gimnazjów ze szkół promujących zdrowie i szkół tradycyjnych w całej Polsce. Liczebność próby wyniosła 502 uczniów, w tym 252 dziewcząt i 241 chłopców (płci pozostałych respondentów nie udało się ustalić). Badanie poprzedzono pilotażem, a przeprowadzone zostało w $2004 \mathrm{r}^{17}$

Tabela 1. Częstotliwość spożycia wina przez respondentów w podziale na płeć (w \%)

\begin{tabular}{|l|c|c|}
\hline \multicolumn{1}{|c|}{ Wyszczególnienie } & Kobieta & Mężczyzna \\
\hline Tak, codziennie & 0,8 & 2,5 \\
\hline Raz na kilka dni & 2,0 & 5,9 \\
\hline Sporadycznie na imprezach & 33,6 & 30,1 \\
\hline Raz spróbowałem i na tym koniec & 21,1 & 19,7 \\
\hline Nigdy nie próbowałem & 42,5 & 41,8 \\
\hline Ogółem & 100,0 & 100,0 \\
\hline
\end{tabular}

Źródło: obliczenia własne na podstawie badań terenowych.

Z przeprowadzonych badań wynika, że chłopcy częściej sięgają po wszystkie gatunki alkoholu, poczynając od piwa, wina oraz wódki, i to zarówno codziennie, jak i kilka razy w tygodniu. Natomiast dziewczęta zdecydowanie częściej deklarują „raz spróbowałam i na tym koniec” oraz "nigdy nie próbowałam” (również dotyczy to wszystkich typów alkoholi). I tak w przypadku wina „spożycie codzienne” i „raz na kilka dni" chłopcy deklarowali odpowiednio w 2,5\% oraz 5,9\%, a dziewczęta - 0,8\% i 2,0\% (tabela 1). W obu przypadkach odnotowane są istotne różnice przy poziomie istotności odpowiednio 0,13 i wyższym oraz 0,04 i wyższym.

Podobne tendencje potwierdzają cykliczne badania nad alkoholizmem młodzieży polskiej z uwzględnieniem płci, przeprowadzane od połowy lat 80., w których uczestniczyli uczniowie trzecich klas gimnazjalnych $\mathrm{z}$ warszawskiego Mokotowa.

16 http://cc.msnscache.com (21.06.2011).

17 W ciągu ostatniego stulecia spożycie alkoholu na świecie wzrosło. Nadużywanie alkoholu jest to jeden z najważniejszych problemów zdrowotnych w wielu krajach. W USA np. nadużycie alkoholu powoduje 100 tys. zgonów rocznie, co czyni go trzecią przyczyną umieralności (po paleniu papierosów i schorzeniach związanych z niewłaściwą dietą oraz siedzącym trybem życia). Choć dokładną liczbę osób uzależnionych od alkoholu trudno oszacować, uważa się, że tylko w Stanach Zjednoczonych mieszka 14-20 mln osób, które są chore w wyniku nadużywania alkoholu. Szacuje się, że 40\% Amerykanów zetknęło się ze skutkami choroby alkoholowej u któregoś z członków rodziny. 
Badania były realizowane przez Pracownię Profilaktyki Młodzieżowej Pro-M Instytutu Psychiatrii i Neurologii w Warszawie w ramach Europejskiego Programu Badań Ankietowych w Szkołach na temat Alkoholu i Narkotyków - ESPAD. Odbywały się w odstępach czteroletnich: pierwsze miało miejsce w 1988 r., a ostatnie w 2011 r. Objęto nimi młodzież w wieku 16 i 18 lat $^{18}$.

Po raz pierwszy od rozpoczęcia badań, tzn. od 1988 r., w 2004 r. obserwowane było zmniejszenie się zachowań ryzykownych określanych m.in. poprzez liczbę osób pijących alkohol (rysunek 3). Może to wynikać ze zmiany sytuacji społecznej w Polsce - po reformie systemu edukacji 15-latki uczące się w pierwszych klasach szkół średnich obecnie znalazły się w gimnazjach.

Drugą bardzo istotną zmianą zaobserwowaną w badaniach z 2004 r. była zwiększająca się grupa dziewcząt sięgająca po alkohol. Trendy te mogą być traktowane jako kierunek przemian obyczajowych obserwowanych od połowy lat 90 . W 2000 r. po raz pierwszy doszło do: wyrównania się wskaźników upijania się i używania narkotyków wśród chłopców i dziewcząt, a w 2004 r. dziewczęta intensywniej niż chłopcy piły alkohol i paliły tytoń (rysunek 3).

\section{Rysunek 3. Spożycie alkoholu, narkotyków i papierosów przez młodzież wybranych szkół Mokotowa w latach 1988-2004 (w \%)}

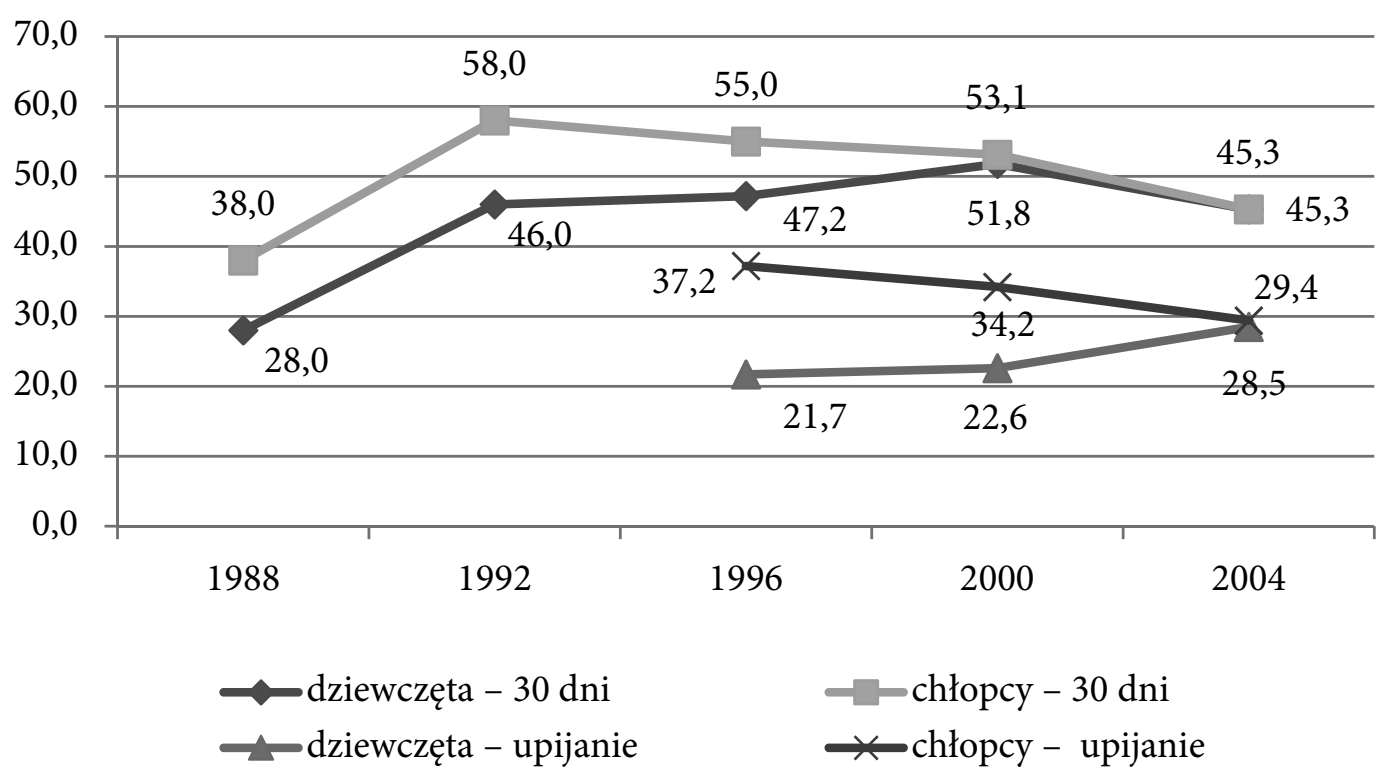

Źródło: www.espad.org raport europejski (15.08.2012).

18 Zdecydowana większość ankietowanych uczniów uczęszczała do trzecich klas gimnazjów lub pierwszych klas szkół ponadgimnazjalnych (licea ogólnokształcące, technika i zasadnicze szkoły zawodowe). 
Wyniki badań w ramach ESPAD potwierdzają, że:

- napoje alkoholowe są najbardziej rozpowszechnioną substancją psychoaktywną używaną przez młodzież; najczęściej spożywanym napojem alkoholowym jest piwo;

- spada liczba abstynentów szczególnie wśród chłopców, wzrasta zaś częstość picia oraz ilość jednorazowo wypijanego alkoholu przez młodzież; ponad 2/3 chłopców $(76 \%)$ oraz ponad połowa dziewcząt (62\%) uczących się w trzecich klasach gimnazjalnych (15-16-latków) piła alkohol w okresie jednego miesiąca przed badaniem ${ }^{19}$;

- do upicia się w czasie ostatniego roku przed badaniem przyznało się niemal 50\% 15-latków (58\% chłopców i 40\% dziewcząt) i ponad 65\% 17-latków (74\% chłopców i 54\% dziewcząt);

- większość uczniów trzecich klas gimnazjów przyznaje się do podejmowania prób zakupu alkoholu (np. piwa 64\%), zdecydowana większość takich prób kończy się powodzeniem; odmową sprzedaży ze względu na zbyt młody wiek kończy się tylko 10\% prób zakupu (dwukrotny wzrost w porównaniu z rokiem 1999).

Podsumowując problem alkoholizmu w Polsce z uwzględnieniem płci, należy stwierdzić, że osiem razy częściej uzależniają się mężczyźni. Mężczyźni piją najwięcej między 20 a 30 rokiem życia, kobiety - między 30 a 40 rokiem życia. Około 4,5 mln osób nadużywa alkoholu, w tym około milion jest uzależnionych i wymaga leczenia. W Polsce przeważa spożycie mocnych napojów alkoholowych oraz obyczaj picia ponad miarę. Grupę osób intensywnie pijących szacowano w połowie lat 70.na $5 \mathrm{mln}$, co stanowi około $23 \%$ ludności w wieku produkcyjnym. W ostatnich latach można obserwować zjawisko zwiększonej sprzedaży piwa, nie oznacza to jednak, że napoje mocne straciły na swej popularności. Przyczyny tego zjawiska tkwią w stosunkowo niskiej cenie tego artykułu oraz pewnej modzie i przyzwoleniu społecznym na spożycie tego typu alkoholu szczególnie wśród młodzieży ${ }^{20}$.

\subsection{Narkomania}

W Polsce przeprowadzono badania nad zasięgiem narkomanii wśród młodzieży, które podobnie jak w przypadku alkoholizmu wykonane były przez Instytut

19 Jako wskaźnik częstej konsumpcji traktowane jest picie alkoholu w ciągu ostatniego miesiąca poprzedzającego badanie.

${ }^{20}$ V. Korporowicz, Alkoholizm, prostytucja, zakażenia HIV i AIDS, narkomania jako formy wykluczenia społecznego ( $w$ świetle badań), „Studia i Prace KES” 2012, nr 3 (1). 
Psychiatrii i Neurologii. Badania powtarzano wielokrotnie ${ }^{21}$. Można przytoczyć wyniki badań w szkołach wykonanych w latach 1995, 1999, 2003 i 2007 oraz wyniki badań populacji generalnej zrealizowanych w latach 2002 i 2006 przez Krajowe Biuro ds. Przeciwdziałania Narkomanii Młodzieży w ramach cytowanego już Europejskiego Programu Badań Ankietowych w Szkołach na temat Alkoholu i Narkotyków - ESPAD. Badania te pokazały, że chociaż raz w ciągu życia używało tych substancji 10,1\% uczniów trzecich klas gimnazjów w 1995 r., a już 19,2\% w 2003 r. W latach 1999-2003 obserwowany był silny wzrost kontaktów młodzieży z narkotykami ${ }^{22}$.

Mimo wysokiego trendu wzrostu liczby kontaktów z narkotykami pozytywnym aspektem, co potwierdzają dane zawarte na rysunku 4, jest to, że zdecydowana większość respondentów nigdy z substancji psychoaktywnych nie korzystała oraz nastąpiła stabilizacja trendu kontaktu $\mathrm{z}$ narkotykami ${ }^{23}$.

Rysunek 4. Używanie jakiejkolwiek substancji psychoaktywnej w czasie 12 miesięcy według wieku (w \%)

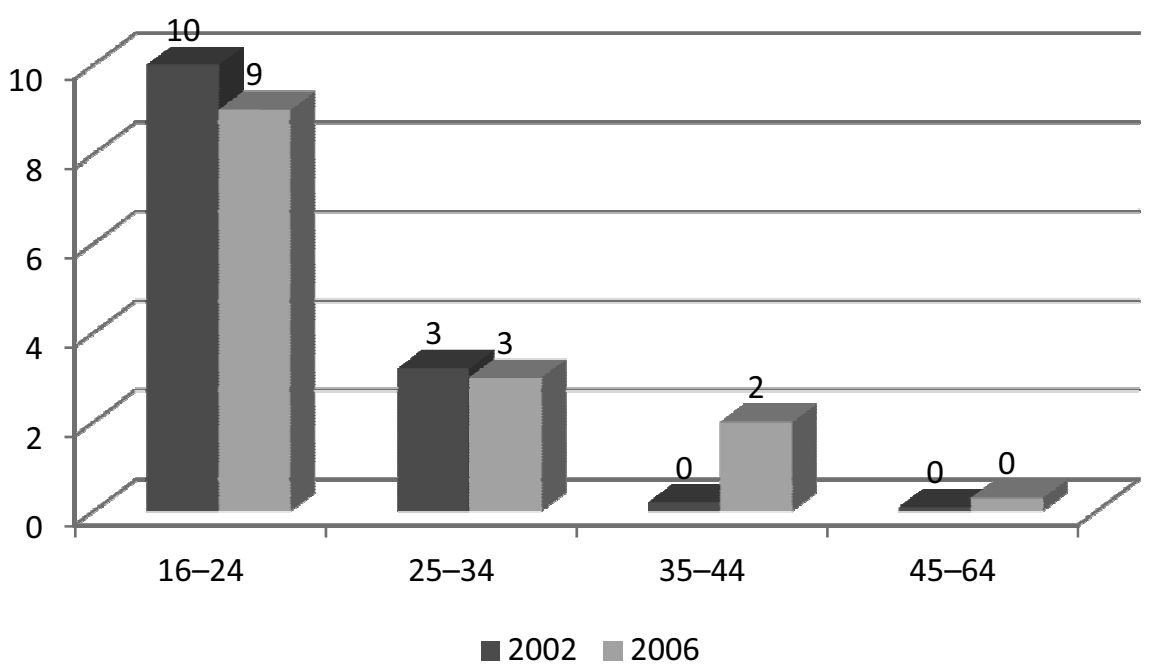

Źródło: http://www.narkomania.org.pl/czytelnia/86 (15.09.2011).

Rysunek 4 potwierdza spadek kontaktu z narkotykami w 2006 r. w porównaniu z 2002 r. młodzieży w wieku 16-24 z 10\% do 9\%, natomiast wzrost spożycia w grupie wiekowej $35-44$ lat z $0 \%$ do $2 \%$.

${ }^{21}$ Narkomania (gr. narke - odurzenie, mania - szaleństwo) - potoczne określenie odnoszące się do uzależnienia od substancji chemicznych wpływających na pracę mózgu.

22 Techniki analiz rzeczywistości odbiegają znacznie od pełnej poprawności metodologicznej, jednakże nieadekwatność istniejących metod pomiaru nie może przeszkadzać w dokonywaniu niezbędnych ocen i prognoz.

${ }^{23}$ The ESPAD Report 2003. Alcohol and Other Drug Use Among Students in 35 European Countries, red. B. Hibell, The Swedish Council for Information on Alcohol and Other Drugs (CAN), The Pompidou Group at the Council of Europe 2004. 
Spośród problemów zdrowotnych związanych z zażywaniem narkotyków do najgroźniejszych należą zgony z powodu przedawkowania oraz zakażenia HIV. Na rysunku 5 zestawiono wskaźniki dynamiki przyjęć ogółem z powodu narkomanii do lecznictwa stacjonarnego, przyjęć pierwszorazowych, zgonów związanych z narkotykami oraz nowych zakażeń HIV wśród osób przyjmujących narkotyki w zastrzykach. Dane te pokazują, że choć zgłaszalność do leczenia traktowana jako wskaźnik narastania liczby narkomanów szybko rośnie, to zarówno zakażenia HIV, jak i zgony pozostają stosunkowo stabilne. Oznacza to, że mimo wzrostu rozpowszechnienia narkomanii nasilenie problemów związanych z narkotykami, przynajmniej tych najbardziej dramatycznych, nie ulega większym zmianom. Stabilizacja rozpowszechnienia tych problemów w dużej części jest efektem realizacji programów redukcji szkód, takich jak wymiana igieł i strzykawek lub edukacja osób zażywających narkotyki w zakresie zwiększania bezpieczeństwa przy używaniu substancji psychoaktywnych. Takie działania znajdują uzasadnienie w trendach zakażeń HIV. Trend nowych zakażeń HIV wśród osób zażywających narkotyki w zastrzykach przebiega zupełnie inaczej niż wśród pozostałych grup. W tym pierwszym przypadku możemy mówić o stabilizacji w ostatnich latach, w drugim widać wyraźny wzrost.

\section{Rysunek 5. Dynamika problemów zdrowotnych związanych} z narkotykami w latach 1990-2006 $(1990=100)$

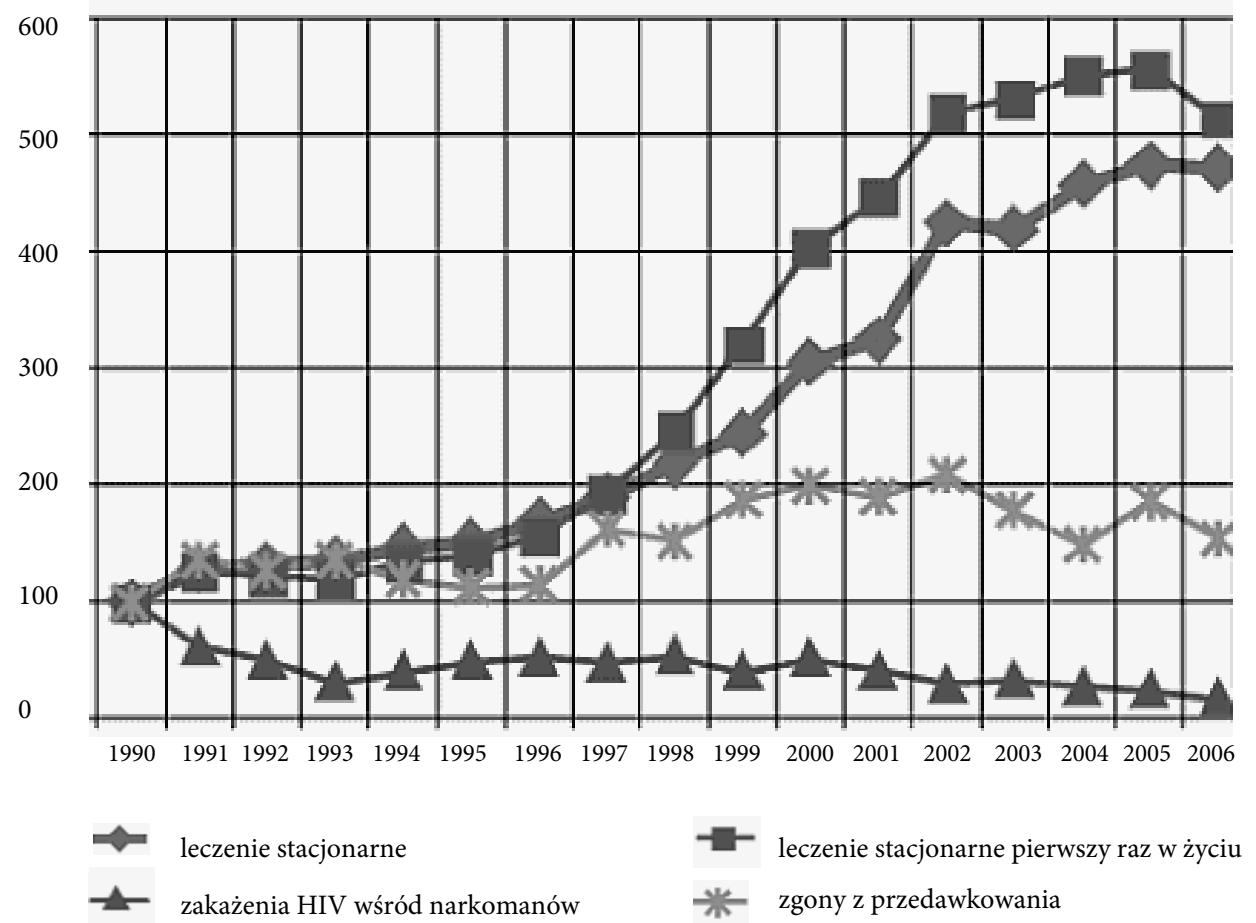

Źródło: http://www.narkomania.org.pl/czytelnia/86,Problem-narkotykow-i-narkomanii -w-Polsce-Rozmiary-i-trendy-zjawiska (11.08.2011). 
W przywoływanym badaniu przeprowadzonym nad postawami i zachowaniami zdrowotnymi młodzieży szkół gimnazjalnych stwierdzono, że podobnie jak w przypadku innych używek, w tym różnego typu alkoholi, chłopcy znacznie częściej niż dziewczęta sięgają po narkotyki. Jest to szczególnie widoczne w odpowiedzi na pytanie dotyczące spożycia „sporadycznie na imprezach": dziewczęta - 3,2, chłopcy - 5,9 oraz „nigdy nie próbowałem” odpowiednio 89,1 oraz 83,5 (tabela 2). W obu przypadkach odnotowane są istotne zależności statystyczne przy poziomie istotności odpowiednio 0,13 i wyższym oraz 0,04 i wyższym.

Tabela 2. Częstotliwość zażywania narkotyków przez respondentów w podziale na płeć (w \%)

\begin{tabular}{|l|r|c|}
\hline \multicolumn{1}{|c|}{ Wyszczególnienie } & Kobieta & Mężczyzna \\
\hline Tak, codziennie & 1,2 & 1,3 \\
\hline Raz na kilka dni & 2,0 & 2,1 \\
\hline Sporadycznie na imprezach & 3,2 & 5,9 \\
\hline Raz spróbowałem i na tym koniec & 4,4 & 7,2 \\
\hline Nigdy nie próbowałem & 89,1 & 83,5 \\
\hline Ogółem & 100,0 & 100,0 \\
\hline
\end{tabular}

Źródło: obliczenia własne na podstawie badań terenowych.

\section{Społeczne koszty leczenia kobiet i mężczyzn w Polsce}

Skutki negatywnych zachowań zdrowotnych po części można analizować poprzez pryzmat ogólnopolskich kosztów leczenia. Same koszty leczenia są to nakłady poniesione na badania, zabiegi ambulatoryjne i operacyjne, pobyt w placówce służby zdrowia oraz zakup niezbędnych lekarstw i środków opatrunkowych ${ }^{24}$. Na ten koszt leczenia składają się liczne koszty, w tym prywatne i publiczne.

$24 \mathrm{~W}$ ekonomii zdrowia do zbadania efektywności leczenia wykorzystuje się inkrementalny współczynnik efektywności kosztów (incremental - cost-effectiveness ratio, zwany często współczynnikiem ICER). Oznacza on koszt interwencji medycznej (zabiegu operacyjnego, badania laboratoryjnego, porady specjalistycznej itp.), który skutkuje pozytywnym efektem zdrowotnym. Ze względu na ograniczone fundusze $\mathrm{w}$ służbie zdrowia współczynnik ten jest bardzo pomocny w podejmowaniu decyzji nad sensem finansowania danej procedury medycznej, np. badań przesiewowych lub refundacji leku.

Wyliczanie kosztów jest łatwiejsze - oznacza całkowity monetarny koszt danej procedury medycznej, zazwyczaj ze strony ubezpieczyciela. Uwzględnianie szerszego, społecznego kontekstu kosztów jest dyskusyjne. Ze względu na różne koszty pracy pracowników służby zdrowia w różnych krajach należy odnosić się z rezerwą do współczynników ICER powstałych $\mathrm{w}$ badaniach $\mathrm{w}$ innych państwach. 
W analizie kosztów leczenia wzięto pod uwagę dane Narodowego Funduszu Zdrowia (NFZ) dotyczące wydatków ze środków publicznych, z uwzględnieniem liczby osób leczonych z podziałem na kobiety i mężczyzn.

Analiza ta dotyczy następujących rodzajów świadczeń:

a) ambulatoryjnej opieki specjalistycznej,

b) leczenia szpitalnego,

c) leczenia stomatologicznego,

d) rehabilitacji leczniczej,

e) opieki psychiatrycznej i leczenia uzależnień,

f) podstawowej opieki zdrowotnej (poz) w zakresie świadczeń lekarskich.

Zapotrzebowanie na usługi ambulatoryjnej opieki specjalistycznej w poszczególnych przedziałach wiekowych przedstawia rysunek 6. Obrazuje on skłonność do korzystania osób ubezpieczonych ze świadczeń opieki zdrowotnej. Do 15 roku życia z ambulatoryjnej opieki specjalistycznej częściej korzystają mężczyźni. Opinie co do przyczyn są różne, ale jedną z nich jest to, że chłopcy rodzą się fizycznie słabsi niż dziewczynki. Potwierdzają to np. statystyki zgonów okołoporodowych i niemowląt, które dla chłopców są wyższe niż dla dziewcząt.

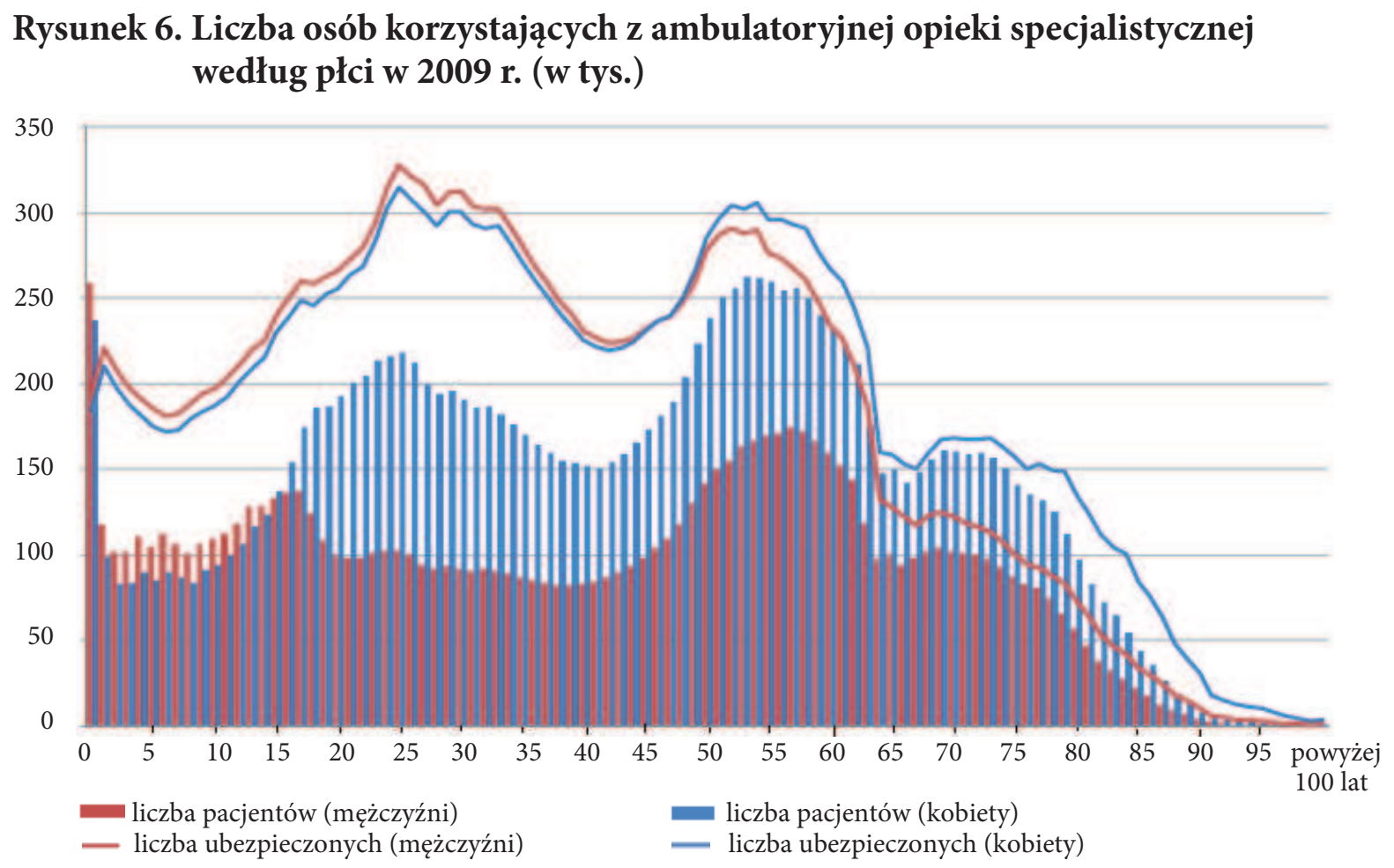

Źródło: Analiza korzystania ze świadczeń opieki zdrowotnej w 2009 r. i rozkładu indywidualnych wydatków NFZ związanych z finansowaniem świadczeń, NFZ, Warszawa 2010, s. 8. 
Jednak po 15 roku życia z ambulatoryjnej opieki specjalistycznej korzystają znacznie częściej kobiety, szczególnie w wieku 20-30 lat, co jest związane z okresem rozrodczym. Natomiast wraz z wiekiem liczba osób korzystających z tego typu opieki zarówno wśród kobiet, jak i mężczyzn spada, co jest związane z naturalnym procesem wymierania ludności.

Jeżeli na różnice w kosztach leczenia między kobietami i mężczyznami spojrzymy poprzez pryzmat wydatków na leczenie jednej osoby w różnych przedziałach wiekowych, okaże się, że od tego okresu wydatki na leczenie mężczyzn w ambulatoryjnej opiece specjalistycznej są wyższe niż kobiet (rysunek 7). Taki trend może być związany z bardziej kosztochłonnymi stanami chorobowymi, jako efekt słabszej profilaktyki chorób, która związana jest $\mathrm{z}$ ograniczonymi wizytami u lekarzy właśnie w ambulatoryjnej opiece specjalistycznej, oraz efektem negatywnych zachowań zdrowotnych, które częściej są rozpowszechnione wśród mężczyzn niż kobiet.

Rysunek 7. Wydatki NFZ na leczenie jednej osoby, która skorzystała z ambulatoryjnej opieki specjalistycznej, według płci w 2009 r. (w zł)

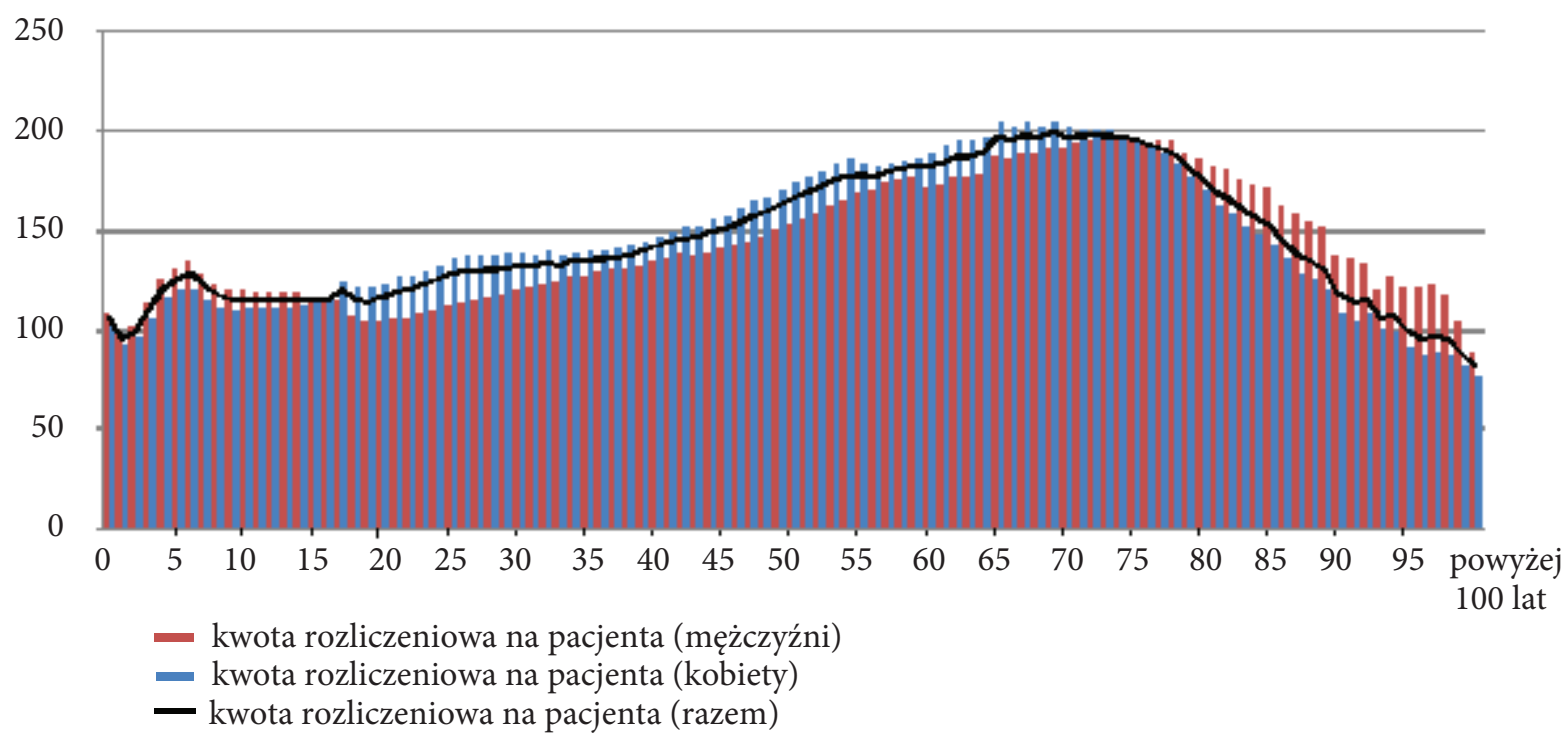

Źródło: Jak do rys. 6, s. 10.

Jak wynika z rysunku 8, również leczenie szpitalne częściej odbywają mężczyźni niż kobiety, pomijając u kobiet przedział między 20 a 45 rokiem życia - okres prokreacyjny. Powyżej 55 roku życia mężczyźni częściej są hospitalizowani niż kobiety, co może mieć również związek z rzadszymi wizytami u lekarzy specjalistów, dzięki czemu można łatwiej uniknąć kosztownych zabiegów leczonych w trybie szpitalnym. 
Rysunek 8. Osoby korzystające ze świadczeń szpitalnych według płci w 2009 r. (w \%)

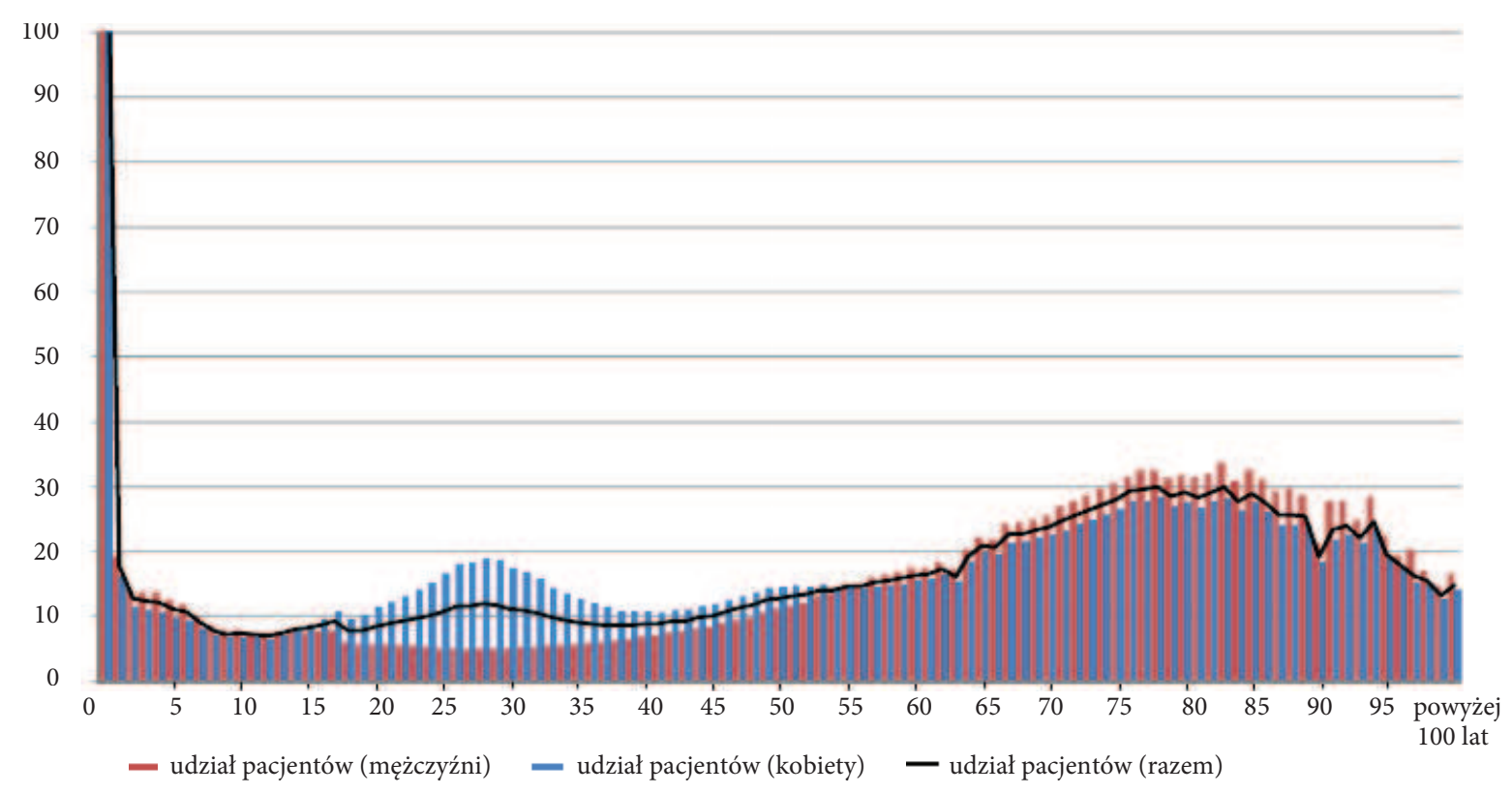

Źródło: jak do rys. 6, s. 12.

Analizując grupę mężczyzn i kobiet korzystających ze świadczeń wypełnianych $\mathrm{w}$ ramach leczenia szpitalnego, obserwuje się naturalny rozkład odpowiadający potrzebom człowieka w poszczególnych etapach życia. Wysoki udział, niezależnie od płci, cechuje pacjentów w pierwszych latach życia oraz kobiety w wieku rozrodczym. Poza tym wysoki udział, a tym samym wysokie zapotrzebowanie na opiekę szpitalną cechuje osoby w wieku starszym, tj. od 65 roku i powyżej, ale nawet w tej dominującej grupie wiekowej do szpitala trafia więcej mężczyzn - 34\% niż kobiet - $28 \%{ }^{25}$.

Liczba osób korzystających z opieki psychiatrycznej i leczenia uzależnień wśród kobiet i mężczyzn jest zbliżona. Szczyt zapotrzebowania na tego typu leczenie przypada na wiek 55 lat, kiedy korzysta z niego więcej kobiet niż mężczyzn (rysunek 9).

Natomiast wydatki na opiekę psychiatryczną i leczenie uzależnień najwyższe są wśród osób mających ponad 50 lat. Koszty tego typu leczenia są niższe dla kobiet. Cechą charakterystyczną nakładów jest przewaga wydatków ponoszonych na leczenie mężczyzn, i to od najmłodszych lat (rysunek 10). Największa dysproporcja w kosztach leczenia między mężczyznami a kobietami przypada na 25-30 lat.

25 Ponieważ leczenie szpitalne częściej dotyka mężczyzn niż kobiet, powoduje relatywnie wyższe koszty leczenia w przeliczeniu na osobę. I tak koszt ten u mężczyzn jest wyższy w porównaniu z kobietami już od 15 roku życia. Dokładnie od tego okresu, kiedy obserwowany jest rzadszy kontakt mężczyzn z lekarzem specjalistą w trybie ambulatoryjnym. 
Rysunek 9. Liczba osób korzystających z opieki psychiatrycznej i leczenia uzależnień według płci w 2009 r. (w tys.)

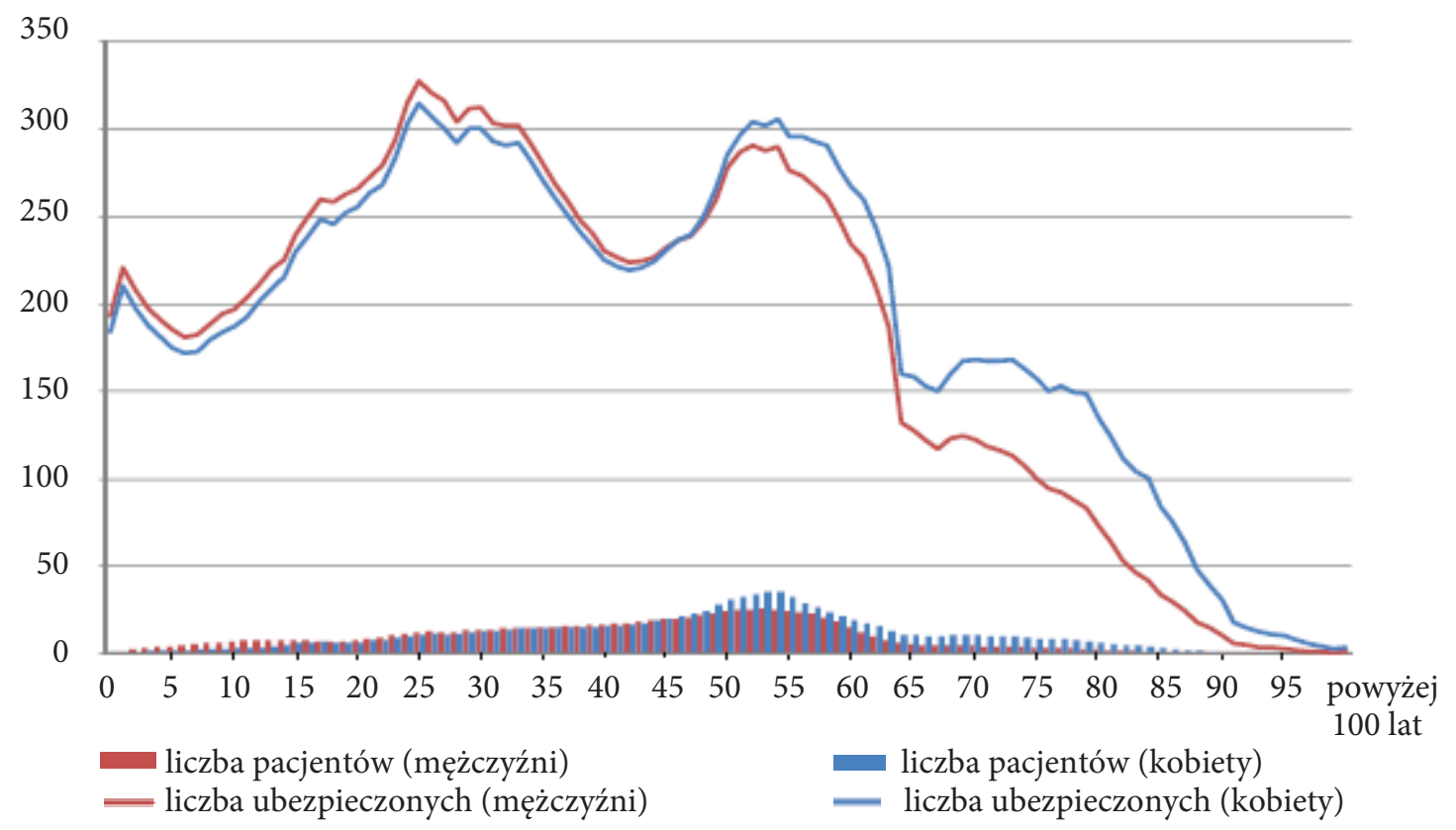

Źródło: jak do rys. 6, s. 15.

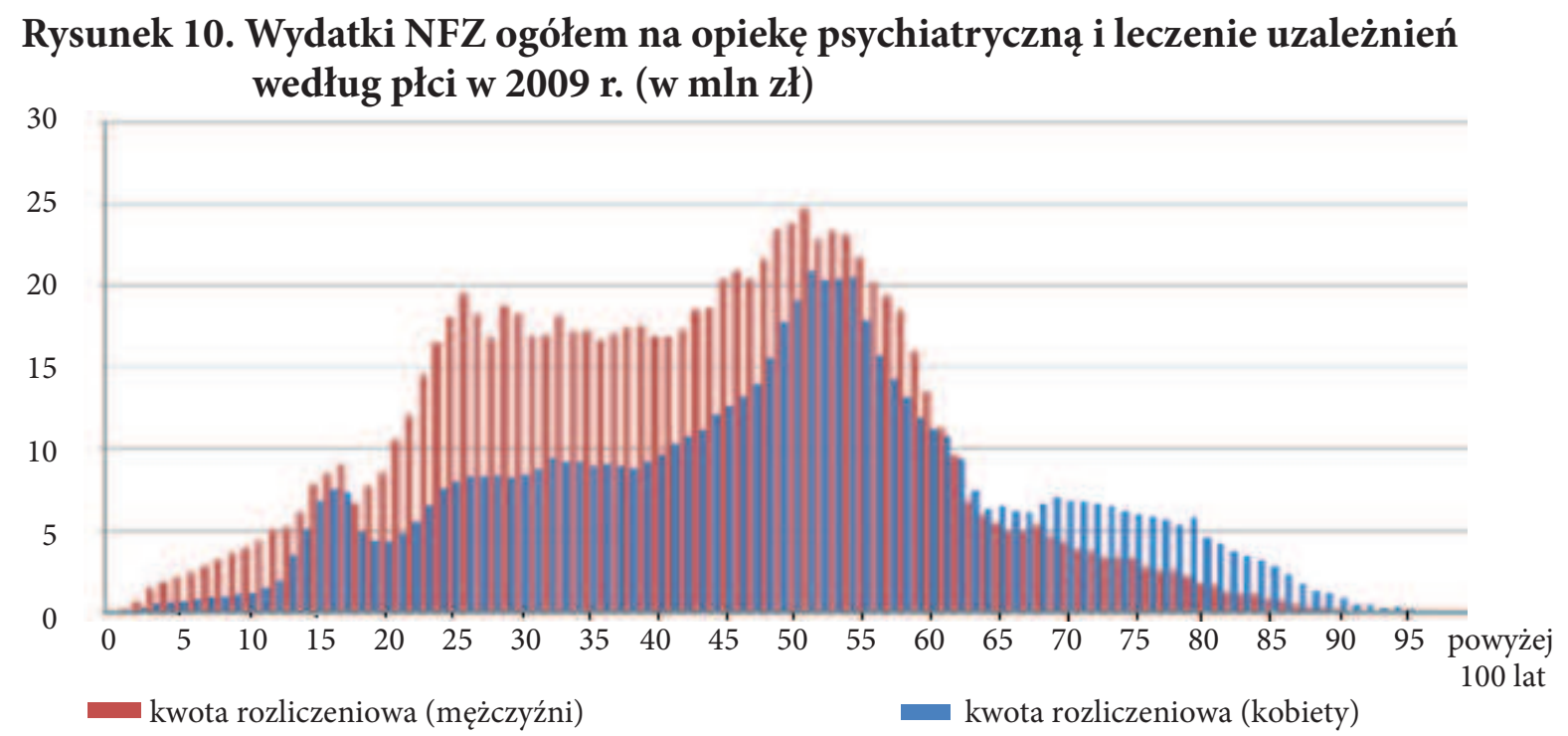

Źródło: jak do rys. 6, s. 16.

W przypadku rehabilitacji leczniczej znacznie większa jest również liczba kobiet w porównaniu z mężczyznami, która korzysta z tego typu leczenia (rysunek 11). Przewaga ta zaczyna się od około 30 roku życia i utrzymuje się aż do 85 roku. Co świadczy, że kobiety częściej zabiegają o sprawność fizyczną, i to do późnej starości. 
Rysunek 11. Udział ubezpieczonych korzystających ze świadczeń w zakresie rehabilitacji według płci w 2009 r. (w \%)

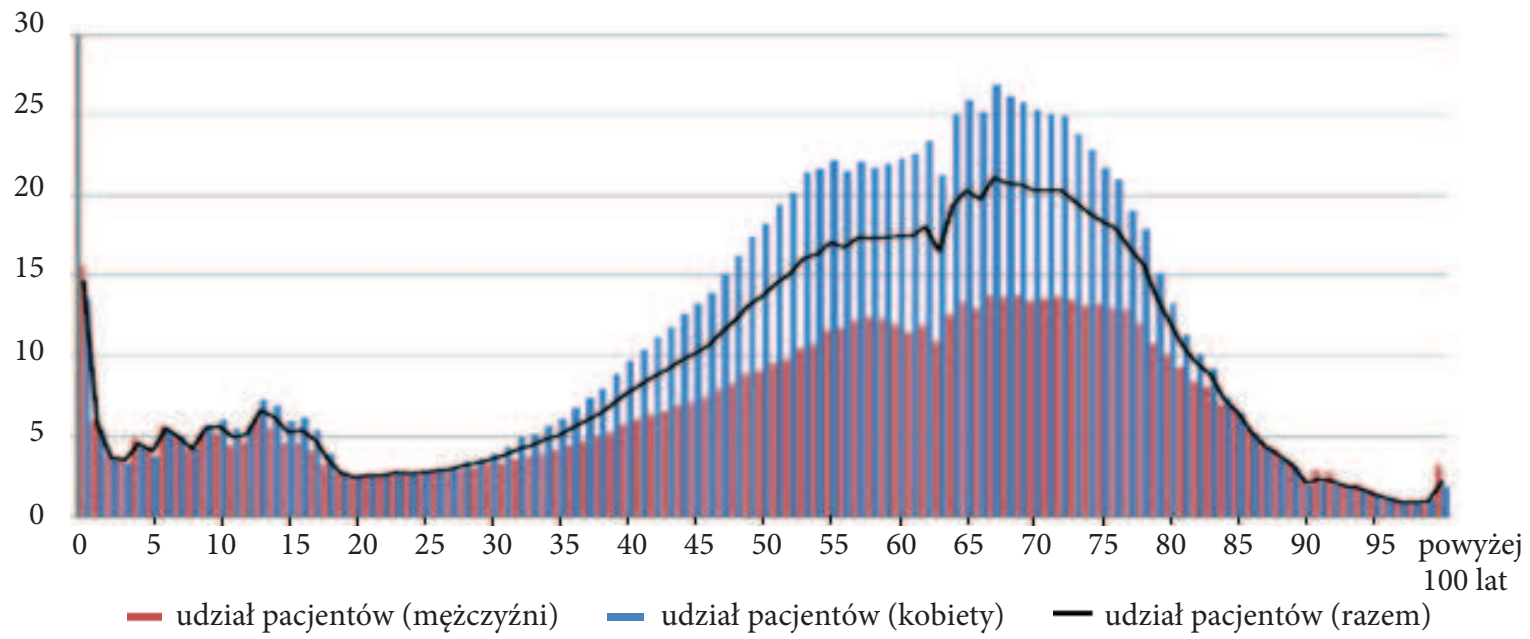

Źródło: jak do rys. 6, s. 18.

O tym, że kobiety bardziej dbają o zdrowie (leczenie ambulatoryjne czy rehabilitacja), świadczą też dane dotyczące leczenia stomatologicznego (rysunek 12). Przewaga udziału kobiet korzystających z usług stomatologicznych utrzymuje się w większości grup wiekowych, poczynając od 10 roku życia aż do późnej starości. Warto też dodać, że z usług stomatologicznych korzysta szczególnie młodzież do 18 roku życia, bowiem refundowany jest tu duży zakres usług, szerszy niż dla osób dorosłych.

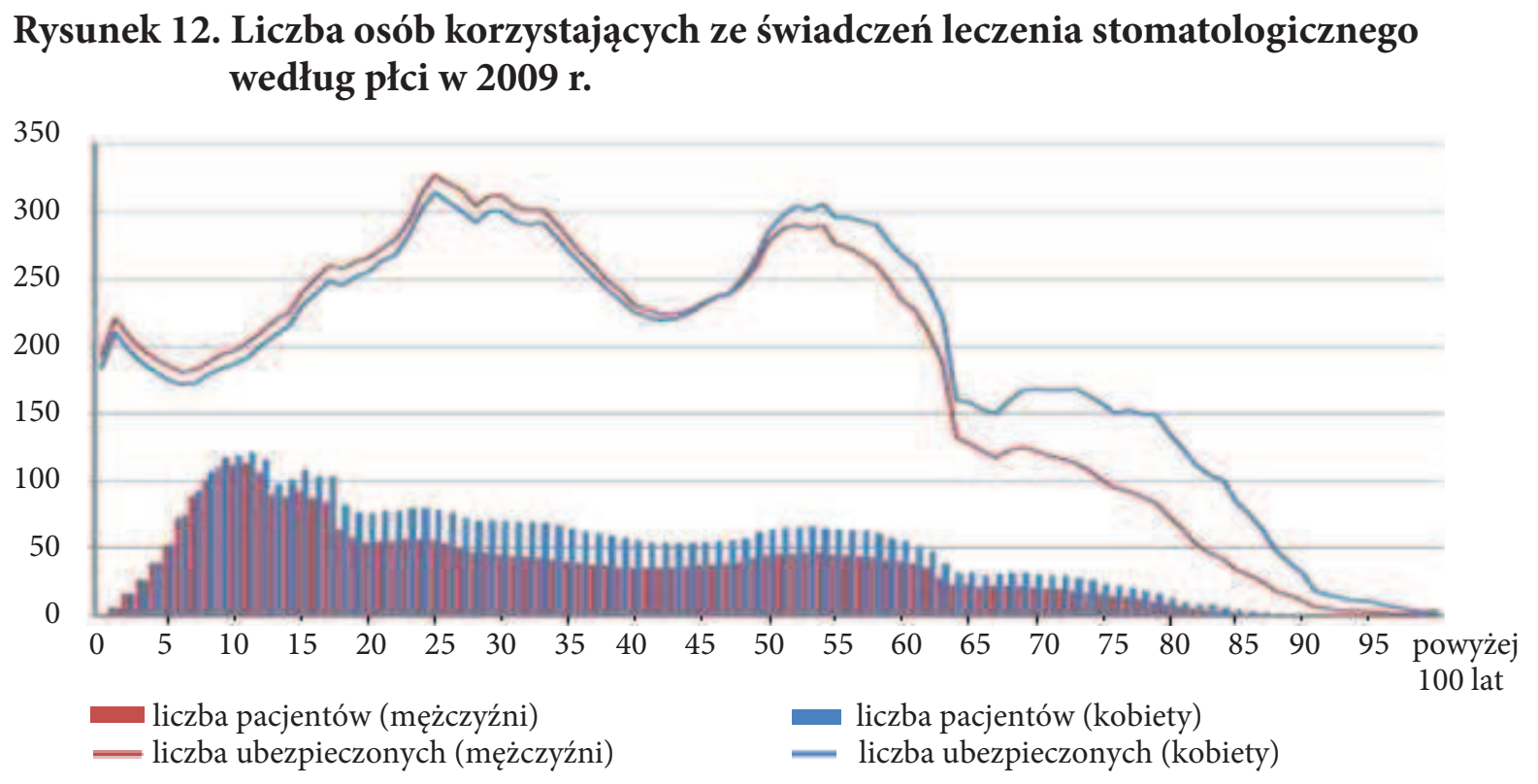

Źródło: jak do rys. 6, s. 21. 
Co do podstawowej opieki zdrowotnej, to również tu widać większą dbałość o zdrowie wśród kobiet, bowiem poczynając od 17 roku życia kobiety częściej niż mężczyźni korzystają z takich świadczeń (rysunek 13).

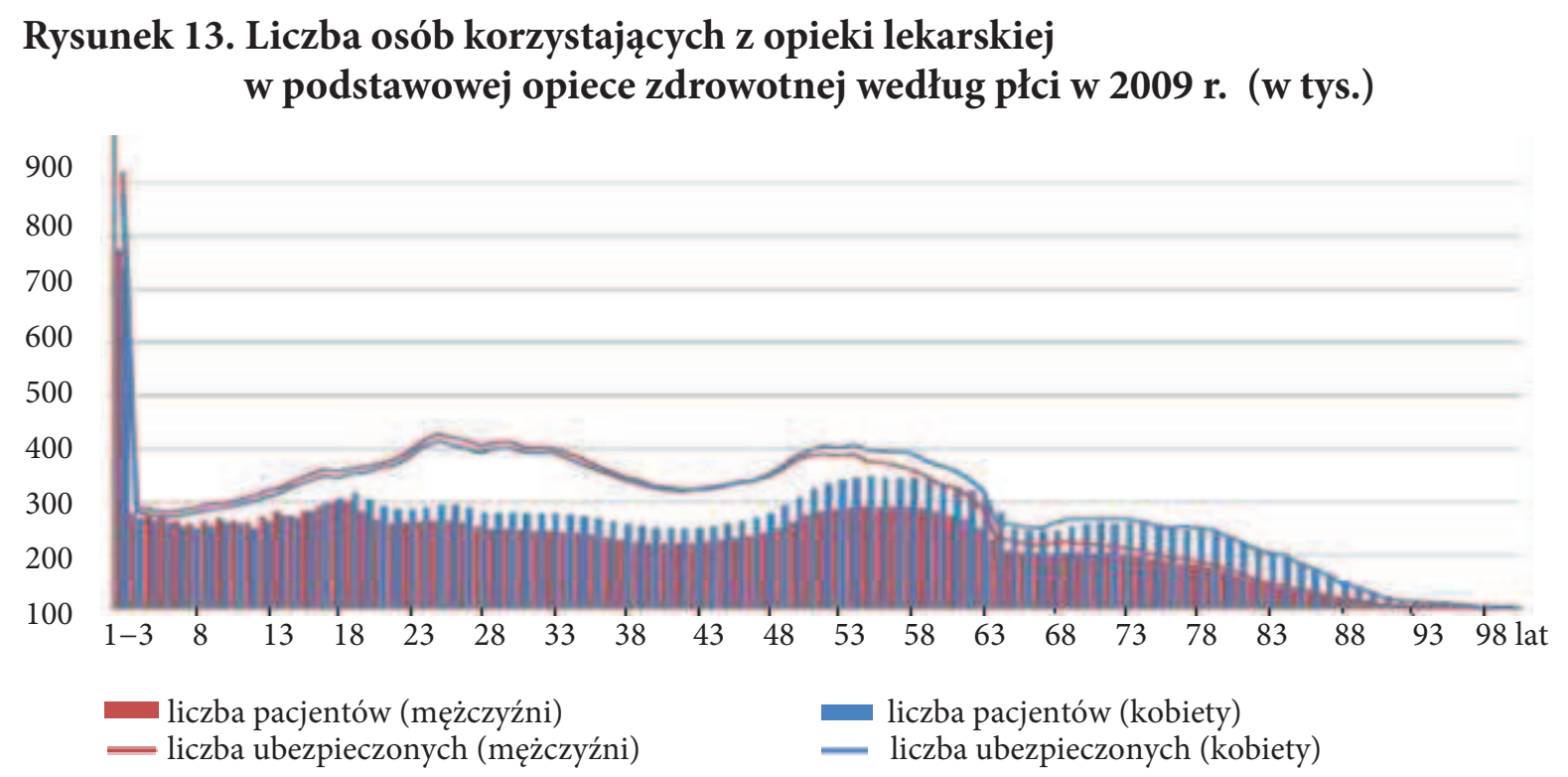

Źródło: jak do rys. 6, s. 24.

W roku 2009 lekarze podstawowej opieki zdrowotnej udzielili w sumie 137653 630 porad, w tym 57318199 mężczyznom i 80335431 kobietom. Średnio na osobę ubezpieczoną przypadło 3,64 porady, dla mężczyzn wskaźnik ten wyniósł 3,14, a dla kobiet 4,12 . Przeliczając liczbę porad w odniesieniu do liczby pacjentów, średnio na pacjenta przypadało 5,87 porady, na mężczyznę - 6,18, kobietę - 5,67.

\section{Podsumowanie}

Zachowania zdrowotne to działania dotyczące stanu zdrowia. W ich skład wchodzą zarówno zachowania wspomagające (pozytywne), jak i szkodzące zdrowiu (negatywne). Wśród zachowań negatywnych dla zdrowia różnicujących kobiety od mężczyzn zaliczyć można częstsze palenie papierosów przez mężczyzn, które powoduje szerzenie się chorób układu krążenia, układu oddechowego i nowotworów złośliwych, a wtórnie inwalidztwo i niezdolność do pracy. W Polsce obserwowane jest duże natężenie palenia, szczególnie wśród mężczyzn, gdyż palą oni średnio o $40 \%$ więcej niż kobiety. Również dane dotyczące spożycia alkoholu wśród dziewcząt i chłopców przed 15 rokiem życia wskazują na wzrost konsumpcji w większości różnych 
kategorii alkoholi. Wskaźniki dotyczące chłopców są znacząco wyższe niż dziewcząt. Podobne wnioski można wysnuć co do częstotliwości zażywania narkotyków przez mężczyzn i kobiety. Z zaprezentowanych danych wynika, że mężczyźni znacznie częściej niż kobiety decydują się na zachowania ryzykowne dla zdrowia.

Trzeba też mieć na uwadze, że dostępne obecnie ilościowe charakterystyki dotyczące alkoholizmu i narkomanii w niepełnym stopniu wydają się odzwierciedlać istniejący stan. Pomimo wielu niedoskonałości statystyki pozwalają np. na szacunkowe określenie rozmiarów problemu czy jego dynamiki, umożliwiając tym samym ocenę zagrożeń związanych z używaniem środków odurzających i podjęcie odpowiednich działań naprawczych.

Analizując zachowania zdrowotne kobiet i mężczyzn w aspekcie liczby pacjentów w sferach: ambulatoryjnej opieki specjalistycznej, leczenia szpitalnego, opieki psychiatrycznej i leczenia uzależnień, rehabilitacji leczniczej i leczenia stomatologicznego, należy stwierdzić, że kobiety częściej korzystają z ambulatoryjnej opieki specjalistycznej, z usług rehabilitacji leczniczej oraz z usług stomatologicznych. W przeciwieństwie do mężczyzn, którzy niechętnie korzystają z usług medycznych. Uzyskane dane pozwalają wnioskować, że właśnie kobiety starają się bardziej niż mężczyźni zapobiegać chorobom, niż leczyć je w stadium zaawansowanym, co powoduje, że powyżej 65 roku życia kobiety rzadziej chorują.

\section{Słowa kluczowe:}

zachowania zdrowotne, koszty leczenia - kobieta, mężczyzna

\section{Keywords:}

health behavior, cost of treatment - woman, man

\section{Differences in health behavior and cost of medical care for woman and man in Poland}

This study aims at analyzing health behavior influencing health according to sex. It also aims at evaluating social and economic consequences of those behaviors.

Shorter male lifespan comparing to woman may be related to more frequent risky behavior: smoking tobacco, drinking alcohol, drug abuse which lead to dysfunctions of circulatory and respiratory systems as well as cancer, disabilities 
and in consequence inability to work. The data presented suggest that man more often than women act in risky manners.

According to collected data, woman more often than man seek specialist ambulatory treatment, medical rehabilitation and dental care. These data may suggest that woman more often try to prevent illness than wait until full treatment is necessary. This may be the reason why older woman ( 65 years old+) less often need expensive hospital treatment.

\section{Les différences dans les comportements de santé et les frais médicaux entre les femmes et les hommes en Pologne}

Les différences dans les comportements de santé entre les femmes et les hommes mènent à d'autres risques potentiels pour la santé en fonction du sexe. Afin d'identifier et d'analyser ces différences, il est important de prendre en compte à la fois les facteurs concernant le comportement et les conditions économiques. Le but de cet article est d'analyser les comportements néfastes pour la santé selon le sexe, ainsi que de tenter dévaluer les conséquences économiques et sociales, qui se manifestent par des coûts plus élevés des services de santé fournis. La raison de l'espérance de vie plus courte des hommes par rapport aux femmes peut être une plus grande fréquence des comportements à risque, qui sont: le tabagisme, la consommation d'alcool et la prise de médicaments - ils causent l'augmentation des maladies du système circulatoire, du système respiratoire et des tumeurs, ainsi que des effets secondaires tels que l'invalidité et l'incapacité à travailler. Les données présentées montrent que les hommes plus souvent que les femmes choisissent les comportements à risque pour la santé.

En analysant les comportements de santé des hommes et des femmes par le nombre de patients dans les domaines suivants - soins ambulatoires spécialisés, soins hospitaliers, traitement de la santé mentale, traitement de la toxicomanie, réadaptation médicale et soins dentaires, il faut conclure que les femmes sont plus susceptibles d'utiliser des soins spécialisés ambulatoires, des services de réadaptation médicale et des services dentaires. Les hommes sont réticents à utiliser ces services médicaux. Dans le même temps, sur la base de ces données, nous pouvons conclure que les femmes sont plus susceptibles de tenter de prévenir les maladies plutôt que de les traiter à un stade avancé. En conséquence, les femmes de plus de 65 ans profitent moins souvent des services hospitaliers, qui sont généralement plus chers. 


\section{Различия в поведении в отношении здоровья и в расходах на медицинские услуги между женщинами и мужчинами в Польше}

Из-за различий в поведении в сфере здоровья между мужским и женским полом вытекают особые потенциальные опасности для здоровья в отношении полов. Выявлять и анализировать эти различия надо через призму как поведенческих, так и экономических детерминант.

Целью данной работы является анализ, учитывая пол, неблагоприятных для здоровья поведениий и попытка оценки их общественных и экономических последствий, проявляющихся ростом стоимости оказываемых медицинских услуг.

Причинами меньшей продолжительности жизни мужчин, по сравнению с женщинами, могут быть более частые опасные для здоровья поведения, которыми являются: курение, употребление алкоголя и наркотиков вызывающие заболевания сердечно-сосудистой системы, дыхательной системы, рак, а в последствии инвалидность и нетрудоспособность. Представленные данные показывают, что мужчины чаще, чем женщины, ведут более опасный для здоровья образ жизни.

Анализируя поведение в отношении здоровья мужчин и женщин по количеству пациентов в области: амбулаторная помощь специалистов, госпитализация, психическое здоровье и лечение зависимостей, реабилитация и стоматологические услуги, следует отметить, что женщины, как правило, чаще пользуются амбулаторной специализированной медицинской помощей, реабилитационными услугами и стоматологическими услугами, в отличие от мужчин, которые неохотно пользуются этими медицинскими услугами. Косвенно, исходя из полученных данных, можно сделать вывод о том, что женщины пытаются больше предотвратить болезнь чем лечить ее на продвинутой стадии. В результате, среди людей старше 65 лет, женщины реже подлежат госпитализации, которая, как правило, дороже. 